Vol. 6(1997): 219-227.

\title{
Production of fungal volatile organic compounds in bedding materials
}

\author{
Sanna Lappalainen \\ University of Kuopio, Department of Environmental Sciences, Kuopio, Finland. Current address: Uusimaa Regional \\ Institute of Occupational Health, Arinatie 3 A, FIN-00370 Helsinki, Finland, \\ e-mail: sanna.lappalainen@occuphealth.fi \\ Anna-Liisa Pasanen, Pertti Pasanen, Pentti Kalliokoski \\ University of Kuopio, Department of Environmental Sciences, PO Box 1627, FIN-70211 Kuopio, Finland
}

\begin{abstract}
The high relative humidity of the air and many potential growth media, such as bedding materials, hay and grains in the horse stable, for example, provide suitable conditions for fungal growth. Metabolic activity of four common agricultural fungi incubated in peat and wood shavings at $25^{\circ} \mathrm{C}$ and $4^{\circ} \mathrm{C}$ was characterized in this study using previously specified volatile metabolites of micro-organisms and $\mathrm{CO}_{2}$ production as indicators. The volatile organic compounds were collected into Tenax resin and analysed by gas chromatography. Several microbial volatile organic compounds (MVOCs), e.g. 1-butanol, 2-hexanone, 2-heptanone, 3-octanone, 1-octen-3-ol and 1-octanol were detected in laboratory experiments; however, these accounted for only $0.08-1.5 \%$ of total volatile organic compounds (TVOCs). Emission rates of MVOCs were $0.001-0.176 \mu \mathrm{g} / \mathrm{kg}$ of bedding materials per hour. Despite some limitations of the analytical method, certain individual MVOCs, 2-hexanone, 2-heptanone and 3-octanone, were also detected in concentrations of less than $4.6 \mu \mathrm{g} / \mathrm{m}^{3}(0.07-0.31 \%$ of TVOC) in a horse stable where peat and shavings were used as bedding materials. MVOC emission rate was estimated to be $0.2-2.0 \mu \mathrm{g} / \mathrm{kg} \times \mathrm{h}^{-1}$ from bedding materials in the stable, being about ten times higher than the rates found in the laboratory experiments. Some compounds, e.g. 3-octanone and 1-octen-3-ol, can be assumed to originate mainly from microbial metabolisms.
\end{abstract}

Key words: agricultural environment, microbial metabolites, microbial volatile organic compounds, peat, total volatile organic compounds, wood shavings

\section{Introduction}

Many reports on levels of volatile organic compounds in houses and offices have recently been published. Concentrations of total volatile organic compounds (TVOCs) have ranged from 20 to
$1900 \mu \mathrm{g} / \mathrm{m}^{3}$ in houses and from 160 to 15300 $\mu \mathrm{g} / \mathrm{m}^{3}$ in office buildings (Miller et al. 1988, Norbäck et al. 1993, Daisey et al. 1994, Ekberg 1994, Kostiainen 1995, Batterman and Peng 1995). Even though epidemiological data are not fully consistent, recent studies have shown an association between TVOC exposure and symp- 


\section{AGRICULTURAL AND FOOD SCIENCE IN FINLAND}

Lappalainen, S. et al. Production of fungal volatile organic compounds

toms. TVOC levels were 5-50 fold higher in "sick houses" than in normal houses (Kostiainen 1995), and significantly higher $(67-8300 \mu \mathrm{g} /$ $\mathrm{m}^{3}$ ) in the dwellings of asthmatics than in those of subjects without such symptoms (Norbäck et al. 1993). Even low concentrations of TVOC may cause irritative symptoms (in the eyes, nose and throat) or headache. Toxic effects may appear when the TVOC concentration exceeds $25 \mathrm{mg} / \mathrm{m}^{3}$ (Mølhave 1990).

Laboratory experiments have shown that micro-organisms, e.g., fungi, produce volatile metabolites, such as 2-methylfuran, 2-methyl-1-propanol, 3-methyl-1-butanol (Börjesson et al. 1989, 1993), 1-octen-3-ol, terpenes (Börjesson et al. 1989, 1990), ethylhexanol (Bjurman and Kristensson 1992, Ezeonu et al. 1994), 1-octanol (Kaminski et al. 1974) and 3-octanone (Kaminski et al. 1974, Börjesson 1993). Production of microbial volatile organic compounds (MVOCs) has been observed to depend on microbial fungal and bacterial species and growth conditions (Kaminski et al. 1974, Börjesson et al. 1989, 1993). MVOCs have also been found in the human environment: Miller et al. (1988) detected several MVOCs, including 2-heptanone, octane, hexanone, 3-methyl-1-butanol and decanol, in the air of "sick buildings" in Canada. Ström et al. (1993) observed that the concentration of MVOCs in houses with microbial problems was significantly higher than that in unaffected houses and outdoor air.

To our knowledge, no reports on TVOC or MVOC levels in the agricultural environment have yet been published so far. The high relative humidity of the air and the many different kinds of substrate such as bedding materials, hay and grains in horse stable, for example, provide good conditions for fungal growth. Airborne fungal spore levels are therefore usually quite high in the agricultural work environment, especially during the handling of hay and grains, when culturable spore concentrations typically range from $10^{5}$ to $10^{6} \mathrm{cfu} / \mathrm{m}^{3}$ in cow sheds (Kotimaa et al. 1984, Pasanen et al. 1989, Hanhela et al. 1995). We investigated here, the production of MVOCs and TVOCs in two bedding materials in labora- tory experiments and determined MVOC and TVOC emissions in a horse stable.

\section{Material and methods}

\section{Laboratory experiments}

\section{Incubation of fungi in bedding materials}

The fungi chosen for this experiment were Fusarium poae, Paecilomyces variotii, Penicillium sp. and Wallemia sebi, all of which occur in abundance in bedding materials (Hanhela et al. 1995). The fungal strains were isolated from the bedding materials, hay and grain used in a horse stable that also served as a sampling site for MVOCs/VOCs in our study. F. poae, P. variotii and Penicillium sp. were cultured on $2 \%$ malt extract agar (MALT) and W. sebi was cultured on dichloral-glycerol agar (DG 18). Four samples of peat and wood shavings, $2 \mathrm{~g}$ of each, were weighed for each experiment. The samples were sterilized at $120^{\circ} \mathrm{C}$ for 30 minutes and stabilized in air-tight chambers $(2 \mathrm{~L})$ at relative humidity of air (RH) $98 \%$ for 2 weeks. After stabilization, the spores of each fungal strain were suspended in sterile water and inoculated on one sample of peat and one of shavings (inoculation strength c. $10^{6} \mathrm{cfu} / \mathrm{g}$ ). Sterilized peat and shavings were used as controls. In addition, clean (not used) and dirty (used as bedding material in a horse stable), non-sterilized peat and shavings were incubated without inoculation of fungi. The samples were prepared for two experiments. The first experiment was carried out at $25^{\circ} \mathrm{C}$ for 6 days, which represented favourable growth conditions for the fungi and the second one at $4^{\circ} \mathrm{C}$ for 22 days, which simulates the winter conditions in stables.

\section{Sampling of volatile compounds}

Volatile organic compounds were collected into Tenax TA resin ( $150 \mathrm{mg}$ per tube) from the chambers at an airflow rate of $100 \mathrm{ml} / \mathrm{min}$ for $10 \mathrm{~min}$. The clean air was led to the chambers through 
Vol. 6 (1997): 219-227.

activated carbon simultaneously with the collection of volatile compounds. In the first experiment (at $25^{\circ} \mathrm{C}$ ), TVOC samples were taken on the fourth day of the incubation, and MVOC samples were collected on the sixth day of the incubation. In the second experiment (at $4^{\circ} \mathrm{C}$ ), only MVOC samples were taken on the 14th and 22nd days of the incubation.

\section{Analysis of volatile compounds}

TVOCs and MVOCs were analysed by gas chromatography (Hewlett Packard 5890) with a mass selective detector (GC-MS, Hewlett Packard 5970) fitted with a Thermal Desorption Cold Trap (TCT) injector. A capillary column $(50 \mathrm{~m}$ x $0.33 \mathrm{~mm}$, BP 10 SEG) was used with helium as the carrier gas. TVOCs were analysed in SCANNING (SCAN, ions 40-260 amu) mode and MVOCs in Selected Ion Monitoring (SIM) mode. The temperature program of the SCANmode was: $40-200^{\circ} \mathrm{C}, 2 \mathrm{~min}$ at the initial temperature, at a rate of $5^{\circ} \mathrm{C} / \mathrm{min}$; that of the SIM mode was: $40-160^{\circ} \mathrm{C}, 2 \mathrm{~min}$ at the initial temperature, at a rate of $5^{\circ} \mathrm{C} / \mathrm{min}$ and $160-200^{\circ} \mathrm{C}$, $20^{\circ} \mathrm{C} / \mathrm{min}$. The compounds were identified using the library of mass spectra (Hewlett Packard 59973B). The SIM mode analysed seven compounds in the first experiment (2-hexanone, 2heptanone, 3-octanone, 1-octen-3-ol, 3-octanol, 2 -octanol and nonanal) and 13 compounds in the second experiment (2-hexanone, 2-heptanone, 3octanone, 1-butanol, 1-octen-3-ol, 1-octanol, 2ethyl-1-hexanol, nonanal, decanal, alfapinene, camphene, betapinene and limonene) all of which are considered to originate from the metabolism of most fungi (Kaminski et al. 1974, Börjesson et al. 1989, 1990, 1993). Deteilas of the sampling and analysis of MVOC have been given in elsewhere (Pasanen et al. 1996). Concentrations of TVOC and MVOC in the air $\left(\mu \mathrm{g} / \mathrm{m}^{3}\right)$ and the rate of MVOC emissions $\left(\mu \mathrm{g} / \mathrm{kg} \times \mathrm{h}^{-1}\right.$ from bedding materials) were calculated.

\section{Measurements of $\mathrm{CO}_{2}$}

The metabolic activity of the fungi was observed by $\mathrm{CO}_{2}$ measurements (ADC analyser, the ana- lytical development, UK) every day in the first experiment and on the 1st, 7th, 14th, 21 st and 22nd days of incubation in the second experiment. $\mathrm{CO}_{2}$ emission rates $\left(\mu \mathrm{g} / \mathrm{kg} \times \mathrm{h}^{-1}\right.$ from bedding materials) were calculated.

\section{Field measurements}

\section{Description of horse stable}

MVOCs and TVOCs were also measured in a stable containing 38 horse stalls and three stalls for horse washing. The floor area was $442 \mathrm{~m}^{2}$ and the volume $1348 \mathrm{~m}^{3}$. The floor area of each stall was $6.25-7.5 \mathrm{~m}^{3}$, and the bedding material was about $10 \mathrm{~cm}$ thick when spread out smoothly. Thus, the mass of the bedding materials used in the whole stable was estimated to be about $3570 \mathrm{~kg}$. The stable was equipped with mechanical ventilation, and the average air flow was approximately $6000 \mathrm{~m}^{3} / \mathrm{h}$. The stable was divided into two equal parts separated by a partial wall. During the measurements peat served as the bedding materials in the first part of stable, and wooden shavings in the second part; normally, shavings were the only bedding material. Two workers fed the horses dry hay and oats three times a day and cleaned the stalls once a day.

\section{Sampling of volatile compounds}

The samples $(n=24)$ were collected at an airflow rate of $100 \mathrm{~mL} / \mathrm{min}$ for $60 \mathrm{~min}$ into Tenax resin at a height of $1.5 \mathrm{~m}$ from four horse stalls where peat or shavings were used as bedding materials. The samples were collected before the workers fed the horses (background) and while they cleaned the stalls. The sampling was carried out in winter and repeated three times ( 2 weeks between each sampling). In addition, three MVOC/ TVOC samples were collected outside the stable and three unused Tenax resin tubes served as controls during the sampling. The samples were analysed by gas chromatography with a mass selective detector as described previously. MVOCs in the first and second measurements were analysed using the same SIM mode as in 
Lappalainen, S. et al. Production of fungal volatile organic compounds

the first laboratory experiment and in the third measurement with the same SIM mode as in the second laboratory experiment.

\section{Results}

\section{Laboratory experiments}

The potential MVOCs detected in the laboratory experiments are presented in Tables 1 and 2 . The sum of MVOC content includes 2-hexanone, 2-heptanone, 3-octanone, 1-butanol, 1-octen-3ol and 1-octanol, all considered to originate from microbes. Note, however, that the results for MVOC in the first and second experiments are not fully comparable, because there were more MVOCs in the SIM mode in the second than in the first experiment. On the other hand, low MVOC concentrations were also detected at the end of experiments in sterilized material samples, indicating slight microbial activity in bedding materials despite sterilization (the concentrations of 2-hexanone, 2-heptanone, 1-octen3 -ol and 1-octanol varied from $<0.4 \mu \mathrm{g} / \mathrm{m}^{3}$ to $33.5 \mu \mathrm{g} / \mathrm{m}^{3}$ ). Only 3-octanone and 1-butanol were not detected in any sterilized material samples. In general, the production of MVOC was 1-100 fold higher in shavings than in peat in both experiments.
The rates of MVOC and $\mathrm{CO}_{2}$ emissions are presented in Table 3. Penicillium sp. grew poorly in peat: in both experiments the $\mathrm{CO}_{2}$ emission rate was at the same level as in sterilized samples. The other fungi grew well in both peat and shavings. $\mathrm{CO}_{2}$ production was $10^{4}-10^{6}$ times higher than the amount of MVOCs released. The rates of MVOC emission from bedding materials ranged from $0.001 \mu \mathrm{g} / \mathrm{kg} \times \mathrm{h}^{-1}$ to $0.176 \mu \mathrm{g} / \mathrm{kg} \times \mathrm{h}^{-1}$.

The concentrations of TVOCs varied from 510 to $3500 \mu \mathrm{g} / \mathrm{m}^{3}$ in the inoculated bedding material samples (Table 1 and 2). The highest TVOC concentration was detected in the nonsterilized, used shavings. TVOC concentrations were $1300 \mu \mathrm{g} / \mathrm{m}^{3}$ in the sterilized peat sample and $3500 \mu \mathrm{g} / \mathrm{m}^{3}$ in the sterilized shavings. Thus, sterilization of bedding materials did not have a major effect on TVOC level. More TVOCs were released from shavings than from peat due to the higher emissions of terpenes from the shavings. However, the level of MVOC was relatively low, comprising about $0.08-1.5 \%$ of the TVOC concentration.

\section{Field measurements}

Low concentrations of MVOCs, such as 2-hexanone $\left(<0.1-0.5 \mu \mathrm{g} / \mathrm{m}^{3}\right), 2$-heptanone $(<0.1 \mu \mathrm{g} /$ $\left.\mathrm{m}^{3}-4.6 \mu \mathrm{g} / \mathrm{m}^{3}\right)$ and 3-octanone $\left(<0.1-1.5 \mu \mathrm{g} / \mathrm{m}^{3}\right)$, were also observed in the air of the horse stable.

Table 1. MVOCs (microbial volatile organic compounds) produced by fungi in bedding materials at $25^{\circ} \mathrm{C}$ for 6 days (Experiment 1). The concentrations of other MVOC analysed (3-octanol, 2-octanol, 1-octanol and nonanal) were below the detection limit, $0.4 \mathrm{ng} /$ single MVOC.

\begin{tabular}{|c|c|c|c|c|c|c|c|c|c|c|c|c|}
\hline & \multicolumn{12}{|c|}{ Concentrations of volatile compounds $\left(\mu \mathrm{g} / \mathrm{m}^{3}\right)$} \\
\hline & \multicolumn{2}{|c|}{$\begin{array}{l}\text { Fusarium } \\
\text { poae }\end{array}$} & \multicolumn{2}{|c|}{$\begin{array}{l}\text { Paecilomyces } \\
\text { variotii }\end{array}$} & \multicolumn{2}{|c|}{$\begin{array}{l}\text { Wallemia } \\
\text { sebi }\end{array}$} & \multicolumn{2}{|c|}{$\begin{array}{l}\text { Penicillium } \\
\text { sp. }\end{array}$} & \multicolumn{2}{|c|}{$\begin{array}{l}\text { not sterilized, } \\
\text { unused }\end{array}$} & \multicolumn{2}{|c|}{$\begin{array}{l}\text { not sterilized, } \\
\text { used }\end{array}$} \\
\hline & peat & shavings & peat & shavings & peat & shavings & peat & shavings & peat & shavings & peat & shavings \\
\hline 2-hexanone & 1.5 & 3.9 & nd & 4.7 & 0.4 & 8.4 & 1.7 & 8.6 & nd & 41.5 & nd & nd \\
\hline 2-heptanone & 5.1 & 16.5 & 5 & 50.6 & 1.9 & 23.3 & 6.1 & 38.4 & 1.1 & 55.3 & nd & nd \\
\hline 3-octanone & nd & nd & nd & nd & nd & nd & nd & 7.5 & nd & nd & nd & nd \\
\hline 1-octen-3-ol & nd & 3.9 & nd & nd & nd & nd & nd & nd & nd & 9.8 & nd & nd \\
\hline sum of MVOC & 6.6 & 24.3 & 5.0 & 55.3 & 2.3 & 32.7 & 7.8 & 54.5 & 1.1 & 106.6 & nd & nd \\
\hline
\end{tabular}

nd = not detected; concentration below the detection limit 
Vol. 6 (1997): 219-227.

Table 2. MVOCs (microbial volatile organic compounds) produced by fungi on bedding materials at $4 \mathrm{C}$ for 22 days (Experiment 2). MVOCs were collected on the 14th day and 22nd day of incubation and MVOC concentrations are presented as the average of those two concentrations. The concentrations of other compounds analysed (3-octanol, 2-octanol, 2-methylfuran, 2-methyl-1-propanol and 3-methyl-2-butanol) were below the detection limit, $0.4 \mathrm{ng} / \mathrm{single} \mathrm{MVOC.}$

\begin{tabular}{|c|c|c|c|c|c|c|c|c|c|c|c|c|}
\hline & \multicolumn{12}{|c|}{ Production of volatile compounds $\left(\mu \mathrm{g} / \mathrm{m}^{3}\right)$} \\
\hline & \multicolumn{2}{|c|}{$\begin{array}{l}\text { Fusarium } \\
\text { poae }\end{array}$} & \multicolumn{2}{|c|}{$\begin{array}{l}\text { Paecilomyces } \\
\text { variotii }\end{array}$} & \multicolumn{2}{|c|}{$\begin{array}{l}\text { Wallemia } \\
\text { sebi }\end{array}$} & \multicolumn{2}{|c|}{$\begin{array}{l}\text { Penicillium } \\
\text { sp. }\end{array}$} & \multicolumn{2}{|c|}{$\begin{array}{l}\text { not sterilized, } \\
\text { unused }\end{array}$} & \multicolumn{2}{|c|}{$\begin{array}{l}\text { not sterilized, } \\
\text { used }\end{array}$} \\
\hline & peat & shavings & peat & shavings & peat & shavings & peat & shavings & peat & shavings & peat & shavings \\
\hline 2-hexanone & nd & nd & nd & nd & nd & nd & nd & nd & nd & 16.2 & nd & nd \\
\hline 2-heptanone & $1.8^{\mathrm{x}}$ & $25^{\mathrm{x}}$ & $2.2^{\mathrm{x}}$ & 10.6 & nd & $15.5^{x}$ & nd & 4.2 & nd & 23.6 & nd & nd \\
\hline 3-octanone & 8.2 & $12.9^{x}$ & 6.9 & 8.4 & nd & $14.9^{\mathrm{x}}$ & $4.1^{x}$ & nd & nd & 29.3 & nd & nd \\
\hline 1-butanol & $12.4^{x}$ & $12.0^{x}$ & nd & nd & nd & nd & nd & nd & nd & nd & nd & nd \\
\hline 1-octen-3-ol & nd & $18.2^{x}$ & nd & $10.2^{x}$ & nd & $13.6^{x}$ & nd & nd & nd & 19.9 & nd & nd \\
\hline 1-octanol & nd & $2.5^{x}$ & nd & nd & nd & nd & nd & nd & nd & nd & nd & nd \\
\hline 2-ethyl-1-hexanol & 6.0 & 7.1 & 4.9 & $6.5^{x}$ & 4.9 & 4.9 & 4.3 & 6.3 & $1.6^{*}$ & 6.5 & 4.2 & 2.6 \\
\hline nonanal & 12.8 & 12.5 & 13.0 & 11.9 & 16.3 & 10.5 & 11.2 & 13.2 & $16.6^{*}$ & 12.1 & 14.2 & 16.9 \\
\hline decanal & 14.4 & 16.5 & 14.4 & $14.0^{x}$ & 16.1 & 9.5 & 12.2 & 28.8 & $20.1^{*}$ & 11.3 & 7.4 & 14.5 \\
\hline alfapinene & 27.1 & 458 & 33.2 & 1160 & $33.7^{*}$ & $1010^{*}$ & 20.5 & 1013 & $11.3 *$ & 1019 & 2.7 & $3.2^{x}$ \\
\hline camfene & $3.3^{x}$ & $42.9^{x}$ & nd & 150 & 3.6 & 309 & $3.5^{\mathrm{x}}$ & 115 & $2.4 *$ & 123 & nd & nd \\
\hline betapinene & $4.0^{x}$ & 89.5 & 3.4 & 263 & 3.7 & 257 & 2.6 & 208 & nd & 234 & nd & nd \\
\hline limonene & 3.2 & $63.4^{x}$ & 3.5 & 101 & 4.1 & 85.2 & 3.2 & 69.6 & $2.5^{*}$ & 92.0 & nd & $1.5^{x}$ \\
\hline sum of MVOC & 22.4 & 70.6 & 9.1 & 29.2 & nd & 44.0 & 4.1 & 4.2 & nd & 89.0 & nd & nd \\
\hline
\end{tabular}

nd=not detected; concentration below the detection limit ${ }^{*}=$ concentration based on one value $\quad \mathrm{x}=$ only one value, the second one is below the detection limit

Table 3. MVOCs (microbial volatile organic compounds) and $\mathrm{CO}_{2}$ emission rates from bedding materials when the fungi were incubated in peat and wood shavings. MVOC and $\mathrm{CO}_{2}$ emission rates were calculated after incubation for 6 days at $25^{\circ} \mathrm{C}$ in the first experiment and for 14 days incubation at $4^{\circ} \mathrm{C}$ (except for W. sebi after incubation for 22 days) in the second experiment.

\begin{tabular}{|c|c|c|c|c|c|c|c|c|}
\hline & \multicolumn{8}{|c|}{ MVOC and $\mathrm{CO}_{2}$ emission rates $\left(\mu \mathrm{g} / \mathrm{kg} \cdot \mathrm{h}^{-1}\right.$ from bedding materials) } \\
\hline & \multicolumn{2}{|c|}{ Fusarium poae } & \multicolumn{2}{|c|}{ Paecilomyces variotii } & \multicolumn{2}{|c|}{ Wallemia sebi } & \multicolumn{2}{|c|}{ Penicillium sp. } \\
\hline & peat & shavings & peat & shavings & peat & shavings & peat & shavings \\
\hline \multicolumn{9}{|c|}{ 1st experiment } \\
\hline 2-hexanone & 0.005 & 0.014 & nd & 0.016 & 0.001 & 0.029 & 0.006 & 0.030 \\
\hline 2-heptanone & 0.018 & 0.057 & 0.017 & 0.176 & 0.007 & 0.081 & 0.021 & 0.133 \\
\hline 3-octanone & nd & nd & nd & nd & nd & nd & nd & 0.026 \\
\hline 1-octen-3-ol & nd & 0.014 & nd & nd & nd & nd & nd & nd \\
\hline $\mathrm{CO}_{2}$ & 43000 & 26000 & 34000 & 15000 & 10000 & 7600 & 5900 & 17000 \\
\hline \multicolumn{9}{|c|}{ 2nd experiment } \\
\hline 2-heptanone & 0.003 & 0.037 & 0.003 & 0.021 & nd & 0.015 & nd & 0.008 \\
\hline 3-octanone & 0.013 & 0.019 & 0.005 & 0.013 & nd & 0.014 & 0.006 & nd \\
\hline 1-butanol & 0.019 & 0.018 & nd & nd & nd & nd & nd & nd \\
\hline 1-octen-3-ol & nd & 0.027 & nd & 0.015 & nd & 0.013 & nd & nd \\
\hline 1-octanol & nd & 0.004 & nd & nd & nd & nd & nd & nd \\
\hline $\mathrm{CO}_{2}$ & 4000 & 1800 & 3600 & 8500 & 5600 & 7200 & 2900 & 10000 \\
\hline
\end{tabular}

nd=MVOC content below the detection limit $(0.4 \mathrm{ng} /$ compound $)$ 


\section{AGRICULTURAL AND FOOD SCIENCE IN FINLAND}

Lappalainen, S. et al. Production of fungal volatile organic compounds

Table 4. Concentrations of TVOCs (total volatile organic compounds) in the stable. The samples were collected three times from two stalls with peat and two stalls with shavings as bedding material. The results are presented as average concentrations of TVOCs in the stalls in each measurement.

\begin{tabular}{|c|c|c|c|c|c|}
\hline \multirow[b]{2}{*}{ measurement } & \multicolumn{5}{|c|}{ Concentrations of TVOC $\left(\mu \mathrm{g} / \mathrm{m}^{3}\right)$} \\
\hline & $1 \mathrm{st}$ & 2nd & 3th & MIN & MAX \\
\hline $\begin{array}{l}\text { Peat } \\
\text { background } \\
\text { cleaning }\end{array}$ & $\begin{array}{l}160 \\
170^{*}\end{array}$ & $\begin{array}{l}210 \\
130^{*}\end{array}$ & $\begin{array}{l}1300 \\
1500\end{array}$ & $\begin{array}{l}140 \\
130\end{array}$ & $\begin{array}{l}1800 \\
1500\end{array}$ \\
\hline $\begin{array}{l}\text { Shavings } \\
\text { background } \\
\text { cleaning }\end{array}$ & $\begin{array}{l}340 \\
610\end{array}$ & $\begin{array}{l}250 \\
290\end{array}$ & $\begin{array}{c}970^{*} \\
1400\end{array}$ & $\begin{array}{l}190 \\
190\end{array}$ & $\begin{array}{r}970 \\
1500\end{array}$ \\
\hline Outdoor & $100^{*}$ & $220^{*}$ & $150^{*}$ & 100 & 220 \\
\hline
\end{tabular}

${ }^{*}=$ concentration based on one value

TVOC concentrations varied from $130 \mu \mathrm{g} / \mathrm{m}^{3}$ to $1800 \mu \mathrm{g} / \mathrm{m}^{3}$ (Table 4). In measurements 1 and 2 , TVOC concentrations were slightly higher in the horse stalls with shavings as bedding material. In contrast, in the third measurement, TVOC concentrations were higher in the stalls with peat as bedding materials. TVOC concentrations were highest in the stable in the third measurement. Cleaning a stall caused no marked difference in TVOC and MVOC concentrations in the air. Terpenes, such as alfapinene, camphene, betapinene and limonene, which were mainly emitted from bedding materials, were detected in concentrations of from $0.1 \mu \mathrm{g} / \mathrm{m}^{3}$ to $23.6 \mu \mathrm{g} / \mathrm{m}^{3}$. In outdoor air, TVOC levels ranged from 100 to $220 \mu \mathrm{g} / \mathrm{m}^{3}$ and MVOC concentrations were below $0.1 \mu \mathrm{g} / \mathrm{m}^{3}$. In the unused Tenax tubes, the background MVOC concentrations varied from $<0.0004$ to $0.0550 \mu \mathrm{g} / \mathrm{m}^{3}$ and TVOC concentrations from 0.6 to $5.1 \mu \mathrm{g} / \mathrm{m}^{3}$.

In the first and second measurements, the rate of MVOC emissions from bedding materials in the stable was $0.224 \mu \mathrm{g} / \mathrm{kg} \times \mathrm{h}^{-1}$ for 2-hexanone and $1.975 \mu \mathrm{g} / \mathrm{kg} \times \mathrm{h}^{-1}$ for 2-heptanone. In the third measurement, the rate of MVOC emission was $0.42 \mu \mathrm{g} / \mathrm{kg} \times \mathrm{h}^{-1}$ for 2-heptanone and

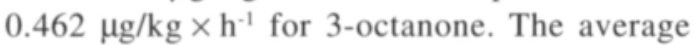
rate of MVOC emissions for most of the MVOCs was about 10 times higher in the stable than that determined in the laboratory.

\section{Discussion}

Volatile compounds, e.g. 1-butanol, 2-hexanone, 2-heptanone, 3-octanone, 1-octen-3-ol and 1-octanol, have been reported to derive from fungal metabolisms (Kaminski et al. 1974, Miller et al. 1988, Börjesson et al. 1989, Börjesson et al. 1993). Here, the same compounds were detected both in the laboratory experiments and in the horse stable as a result of microbial, especially fungal, activity and metabolism. Extreme caution should, however, be exercised before concluding that MVOCs indicate microbial activity; in our experiments, for example, terpenes probably derived mainly from the bedding material itself, although some fungi are capable of producing terpenes in their metabolisms (Börjesson et al. 1989, Börjesson et al. 1990). Nonanal and decanal are common impurities both indoors and outdoors, even in remote areas (Yokouchi et al. 1990, Brown et al. 1994). Likewise 2-ethyl1-hexanol has been found to originate in different materials (e.g. plastics) and to be a frequent pollutant in indoor air (Pleil and Whiton 1990, Brown et al. 1994). Therefore, nonanal, decanal and 2-ethyl-1-hexanol were here excluded from the sum of MVOC content.

In the laboratory experiments, the rate of 2-hexanone, 2-heptanone, 3-octanone, 1-butanol, 


\section{AGRICULTURAL AND FOOD SCIENCE IN FINLAND}

Vol. 6(1997): 219-227.

1-octen-3-ol and 1-octanol emissions from peat and shavings $\left(\mu \mathrm{g} / \mathrm{kg} \times \mathrm{h}^{-1}\right)$ ranged from 0.001 to 0.176 . To compare our observations with those of other studies, we calculated the rates of MVOC emissions for a few fungi from MVOC production reported by Börjesson et al. (1989). The MVOC emission rate of Aspergillus flavus in wheat was $0.11 \mu \mathrm{g} / \mathrm{kg} \times \mathrm{h}^{-1}$ for 2-methyl1- propanol after 6 days and $0.96 \mu \mathrm{g} / \mathrm{kg} \times \mathrm{h}^{-1}$ after 14 days; the MVOC emission rate of Aspergillus amstelodami was $0.003 \mu \mathrm{g} / \mathrm{kg} \times \mathrm{h}^{-1}$ for 1 -octen-3-ol after 6 days and $0.002 \mu \mathrm{g} / \mathrm{kg} \times \mathrm{h}^{-1}$ after 14 days. These results agree well with our observations, although different methods were used in the studies. Note, however, that we determined emissions of only some MVOCs and that our sampling and analysis method was not necessarily sensitive to all the MVOCs analysed. For example, it is known that sampling into Tenax TA resin and analysis by the TCT-GC-MS method is not suitable for very volatile compounds (those with less than six carbons) (Knöppel 1992). In addition, the rate of MVOC emission probably varies with time. These factors may explain why MVOC emissions were several orders of magnitude lower that those of $\mathrm{CO}_{2}$.

The rate of 2-hexanone, 2-heptanone and 3octanone emission from bedding materials in the stable was $0.2-2.0 \mu \mathrm{g} / \mathrm{kg} \times \mathrm{h}^{-1}$. Emissions were about one order of magnitude higher in the stable than in the laboratory, possibly because of the abundance and diversity of microbial species in the stable. Another reason for the significant difference in emissions between environmental and laboratory studies may be the varie- ty of humidity and the presence of other biological contaminants under field conditions. Furthermore, the MVOC content detected in the horse stable was due not only to emissions from bedding materials but also to those from hay and grain or other favourable substrates for fungal growth. Above all, MVOC accounted for only $0.07-0.31 \%$ of the TVOC content in the horse stable. Therefore it would be very difficult to evaluate a stage of microbial activity and a quantity of microbes on the basis of MVOCs alone. A few quite high concentrations of TVOC were measured in the stable as background levels $\left(1800 \mu \mathrm{g} / \mathrm{m}^{3}\right)$ and when the stalls were cleaned $\left(1500 \mu \mathrm{g} / \mathrm{m}^{3}, 1400 \mu \mathrm{g} / \mathrm{m}^{3}\right)$.

The present study showed that some compounds, such as 2-hexanone, 2-heptanone, 3-octanone, 1-octen-3-ol, 1-butanol and 1-octanol, can be assumed to originate mainly from microbial metabolism and that the same compounds can also be detected in a horse stable. Thus, the presence of these compounds and other MVOCs may indicated microbial contamination and activity in an agricultural environments. On the other hand, MVOC analyses do not replace microbiological methods because microbial species cannot be identified or quantified on the basis of MVOC profiles. Furthermore, high concentrations of various other volatile organic compounds severely limit the use of MVOCs as indicators of microbial contamination in practice, because small sample volumes should then have to be used to avoid the breakthrough of VOCs in a resin, which, in turn, would increase the detection limit of MVOC analyses.

\section{References}

Batterman, S. \& Peng, C.-U. 1995. TVOC and $\mathrm{CO}_{2}$ concentrations as indicators in indoor air quality studies. American Industrial Hygiene Association Journal 6: 55-65.

Bjurman, J. \& Kristensson, J. 1992. Volatile production by Aspergillus versicolor as a possible cause of odor in houses affected by fungi. Mycopathologia 118 : 173-178.

Börjesson, T., Stöllman, U., Adamek, P. \& Kaspersson, A. 1989. Analysis of volatile compounds for detection of molds in stored cereals. Cereal Chemistry 66: 300-304. 


\title{
AGRICULTURAL AND FOOD SCIENCE IN FINLAND
}

\author{
Lappalainen, S. et al. Production of fungal volatile organic compounds
}

- , Stöllman, U. \& Schnürer, J. 1990. Volatile metabolites and other indicators of Penicillium aurantiogriseum growth on different substrates. Applied and Environmental Microbiology 56: 3705-3710.

- , Stöllman, U.M. \& Schnürer, J.L. 1993. Off-odorous compounds produced by molds on oatmeal agar: Identification and relation to other growth characteristics. Journal of Agricultural Food Chemistry 41: 2104-2111.

Brown, S.K., Sim, M.R., Abramson, M.J. \& Gray, C.N. 1994. Concentrations of volatile organic compounds in indoor air - a review. Indoor Air 4: 123-134.

Daisey, J.M., Hodgson, A.T., Fisk, W.J, Mendell, M.J. \& Brinke, J.T. 1994. Volatile organic compounds in twelve California office buildings: classes, concentrations and sources. Atmospheric Environment 28: 3557-3562.

Ekberg, L.E. 1994. Volatile organic compounds in office buildings. Atmospheric Environment 28: 3571-3575.

Ezeonu, I.M., Price, D.L., Simmons, R.B., Crow, S.A. \& Ahearn, D.G. 1994. Fungal production of volatiles during growth on fiberglass. Applied and Environment Microbiology 60: 4172-4173.

Hanhela, R., Louhelainen, K. \& Pasanen, A.-L. 1995. Prevalence of micro-fungi in Finnish cow-houses some aspects on the occurrence of Wallemia sebi and Fusaria. Scandinavian Journal of Work, Environment \& Health 21: 223-228.

Kaminski, E., Stawicki, S. \& Wasowicz, E. 1974. Volatile flavor compounds produced by molds of Aspergillus, Penicillium and Fungi imperfecti. Applied Microbiology 27: 1001-1004.

Knöppel, H. 1992. Sampling and analysis of organic indoor air pollutants. In: Chemical, Microbiological, Health and Comfort Aspects of Indoor Air Quality State of the Art in SBS. Kluwer Academic Publishers. Dordrecht. p. 37-48.

Kostiainen, R. 1995. Volatile organic compounds in the indoor of normal and sick houses. Atmospheric Environment 29: 693-702.
Kotimaa, M.H., Husman, K.H., Terho, E.O. \& Mustonen, M.H. 1984. Airborne molds and actinomycets in the work environment of farmer's lung patients in Finland. Scandinacian Journal of Work, Environment \& Health 10: 115-119.

Miller, J.D., Laflamme, A.M., Sobol, Y., Lafontaine, P. \& Greenhalgh, R. 1988. Fungi and fungal products in some Canadian houses. International Biodeterioration 24: 103-120.

Mølhave, L. 1990. Volatile organic compounds, Indoor air quality and health, Indoor Air'90. Proceedings of the 5th International Conference on Indoor Air Quality and Climate. Toronto. p. 15-33.

Norbäck, D., Björnsson, E., Widström, J., Ström, G., Palmgren, U., Jansson, C. \& Boman, G. 1993. Asthma symptoms in relation to volatile organic compounds (VOC) and bacteria in dwellings. In: Volatile Organic Compounds in the Environment. IAI, Lonsdale press, London. p. 377-386.

Pasanen, A.-L., Kalliokoski, P., Pasanen, P., Salmi, T. \& Tossavainen, A. 1989. Fungi carried from farmers' work into farm houses. American Industrial Hygiene Association Journal 50: 631-633.

- , Lappalainen, S. \& Pasanen, P. 1996. Volatile organic metabolites associated with some toxic fungi and their mycotoxins. Analyst 12: 1949-1953.

Pleil, J.D. \& Whiton, R.S. 1990. Determination of organic emissions from new carpeting. Applied Occupational Environment Hygiene 5: 693-699.

Ström, G., Norbäck, D., West, J., Wessen, B. \& Palmgren, U. 1993. Microbial volatile organic compounds (MVOC): a causative agent to sick building problems. In: Sterling, E. et al. (eds.). Building Design, Technology, and Occupant Well-Being in Temparature Climates. ASHRAE, Atlanta. p. 351-357.

Yokouchi, Y., Mukai, H., Nakajima, K. \& Ambe, Y. 1990. Semi-volatile aldehydes as predominant organic gases in remote areas. Atmospheric Environment 24A: 439-442. 
Vol. 6 (1997): 219-227.

\title{
SELOSTUS
}

\section{Haihtuvien orgaanisten yhdisteiden muodostuminen kuivikkeissa}

\author{
Sanna Lappalainen, Anna-Liisa Pasanen, Pertti Pasanen ja Pentti Kalliokoski \\ Kuopion yliopisto ja Uudenmaan aluetyöterveyslaitos
}

\begin{abstract}
Maatalousympäristössä, esim. hevostallissa, on mikrobikasvulle suotuisat olosuhteet: korkea ilman suhteellinen kosteus ja monia potentiaalisia kasvualustoja (esim. rehu, heinä ja kuivikkeet). Tässä työssä tutkittiin neljän yleisesti maatalousympäristössä havaitun sienilajin (Fusarium poae, Paecilomyces variotii, Penicillium sp. ja Wallemia sebi) metabolista aktiivisuutta kuivikemateriaaleilla laboratoriokokeissa. Sieniä kasvatettiin turpeessa ja sahanpurussa 1. laboratoriokokeessa 6 päivää $+25^{\circ} \mathrm{C}$ :ssa ja 2. laboratoriokokeessa 22 päivää $+4{ }^{\circ} \mathrm{C}: s s a$, jolla jäljiteltiin tallin lämpötilaa talvella. Haihtuvat orgaaniset yhdisteet (VOC) kerättiin Tenax-adsorbenttiin ja analysoitiin kaasukromatografi-massaspektometrillä. Yhdisteistä määritettiin haihtuvien orgaanisten yhdisteiden kokonaispitoisuus (TVOC) ja mikrobien tuottamat haihtuvat orgaaniset yhdisteet (MVOC). Näitä yhdisteitä määritettiin samoin analyysimenetelmin myös hevostallin sisäilmasta, jossa käytettiin turvetta ja sahanpurua kuivikkeena.

Laboratoriokokeissa havaittiin useita sienten tuottamia MVOC:eja: 1-butanoli, 2-heksanoni, 3-oktanoni, 1-okteeni-3-oli ja 1-oktanoli. MVOC:it olivat kui-
\end{abstract}

tenkin vain $0,08-1,5 \%$ TVOC:iesta. MVOC:ien emissionopeus kuivikkeista vaihteli välillä 0,001 $0,176 \mu \mathrm{g} /$ kuivikemateriaalikilo tunnissa. Mikrobien metaboliatuotteita, kuten 2-heksanoni, 2-heptanoni ja 3-oktanoni, havaittiin myös tallista; pitoisuudet olivat alle $4,6 \mu \mathrm{g} / \mathrm{m}^{3}(0,07-0,31 \%$ kokonaispitoisuudesta). MVOC emissio kuivikkeista oli tallissa noin 10 kertaa korkeampi kuin laboratoriokokeissa. Tallissa mitatut MVOC:it voivat kuitenkin olla peräisin myös muista kontaminoiduista lähteistä, kuten rehusta ja heinästä.

Tämä tutkimus osoittaa, että jotkin mikrobien metaboliatuotteet, kuten 3-oktanoni ja 1-okteeni-3oli, ovat melko spesifisiä sienten metaboliitteja ja näitä yhdisteitä voidaan havaita myös maatalousympäristöstä. Vaikka MVOC:ien esiintyminen ilmassa viittaa mikrobikontaminaatioon, MVOC-analyysit eivät korvaa mikrobiologisia määrityksiä, koska MVOC-profiilien perusteella ei voida päätellä mikrobien määrää ja lajistoa. Lisäksi metodologisista ongelmista johtuen korkeat TVOC-pitoisuudet rajoittavat MVOC-analyysien käyttöä mikrobikontaminaation tunnistuskeinona. 